\title{
Challenges and Edge of Tuberculosis Diagnostic Techniques
}

\section{IJCRR}

Section: Healthcare

Sci. Journal Impact

Factor: 6.1 (2018)

ICV: 90.90 (2018)

(c) (7) (3)

Copyright@IJCRR

\section{Jyotsana Bhatt', Nidhi Dobhal', Akbar Nawaz ${ }^{2}$}

'School of Pharmacy, Graphic Era Hill University, Dehradun, Uttarakhand, India; ' $G r a p h i c$ Era College of Nursing, Graphic Era

(Deemed to be University), Dehradun, Uttarakhand, India.

\section{ABSTRACT}

Aim: Tuberculosis remains the most deadly infectious killer affecting about one-quarter of the world population. Early diagnosis and correct detection of TB has always been a challenge since its discovery in 1882. The economic burden in low- and middleincome countries is estimated to be US $\$ 10.1$ billion in 2019. It is necessary to analyze the current tuberculosis diagnostic techniques and understands their advantages and limitations for future advancement.

Observation: The current status of tuberculosis necessitates advancement in diagnostic techniques. In recent years with the initiatives taken by WHO, various new diagnosis techniques have been introduced to the world. Techniques such as Fluorescent microscopy and bleach microscopy with their improved sensitivity are proposed to give a new face to the microscopy. Whereas molecular techniques such as Cartridge based NAAT and line probe assay are also proving their potential. Culture techniques such as MB/BacT, Versa TREK/ESP, and Thin layer agar cannot be replaced for their sensitivity and specificity, but they are required to be used alongside new techniques. Novel techniques such as biosensors with the aid of their higher sensitivity, low detection cost, and simple methodology are paving a better future for the world.

Conclusion: Despite the long list of conventional diagnostic techniques, early and precise diagnosis of tuberculosis is still a challenge in developing countries. For the complete eradication of tuberculosis from world, we need to focus on developing new diagnostic techniques and also increase awareness about the existing techniques.

Key Words: Tuberculosis, Microscopy, Nucleic acid amplification test, Biosensors, Transducer, Multi drug-resistant

\section{INTRODUCTION}

Tuberculosis caused by Mycobacterium tuberculosis, is a bacterial disease that mainly affect the lungs leading to severe coughing, fever, and chest pains. Tuberculosis has been a global health concern because it is the world's leading fatal disease. In the early 1800 s, the people infected with tuberculosis were advised to "Just sleep rest and eat healthy and nutritious food". But the scenario changed with the advancement in the area of science and medicine ${ }^{1-2}$.

In 1882, the bacterium that causes tuberculosis i.e., MTb was discovered by German microbiologist Robert Koch. This finding helps in the discovery of tuberculin (in 1890), Bacillus-Calmette Guerin (BCG) vaccine (in 1908), and later anti-tuberculosis drugs.

Tuberculosis is a curable disease but its early detection, treating it with the right drugs and vaccines, and thereby con- trolling it is very necessary. For the treatment, multiple antibiotics are administered for a considerable period of time, which makes it a challenging task. Along with this multiple drug-resistant tuberculosis (MDR-TB) infections are also an emerging problem. In present, first line anti-TB drugs, second-line anti-TB drugs, and DOTS (Directly Observed Treatment, Short-Course) are used widely to treat and prevent tuberculosis ${ }^{2-4}$.

According to the Global tuberculosis report 2019 by WHO, in the year 2018, almost 10 million people were found to be infected with tuberculosis in all countries out of which 5.7 million infected patients were men, 3.2 million infected women, and 1.1 million cases of children. Along with this, in 2018, around 1.5 million people died from TB. Countries with the highest number of cases are India (27\%), China (9\%), Indonesia (8\%), Philippines (6\%), Pakistan (6), Nigeria (4\%), Bangladesh (4\%), and South Africa (20\%) (Figure 1) .

\section{Corresponding Author:}

Jyotsana Bhatt, Assistant Professor, School of Pharmacy, Graphic Era Hill University, Dehradun, Uttarakhand, India. Email: bhattjigyasha94@gmail.com.

ISSN: 2231-2196 (Print)

Received: 12.06 .2020
ISSN: $0975-5241$ (Online)

Revised: 02.08 .2020
Accepted: 23.08 .2020
Published: 08.09.2020 
On 26 September 2018 United Nations organized a meeting on TB for discussing the present status of TB, it's epidemic, and methods to control this deadly disease in the present and future. In this meeting, a target is decided that is to treat 40 million individuals with TB in between 2018 and 2022. Therefore, according to this target, it is necessary to treat approximately 7 million individuals in 2018. According to WHO, the target for 2018 was achieved. For $2030 \mathrm{WHO}$ has set a target as a $90 \%$ reduction in the number of TB death and a 80\% reduction in TB incidence rate as compared to 2015. For the accomplishment of this goal the WHO has worked on introducing new techniques for early and better diagnosis of TB adding on to the traditional techniques. The traditional techniques used earlier for diagnosis of TB remains the same for quite a decade. But these conventional microscopic techniques fell short in the detection of extra-pulmonary TB and multidrug-resistant TB. So, to overcome the limitation of conventional techniques WHO took some initiatives and worked out new techniques that are more efficient, less time consuming, and economical for the estimation of tuberculo$\operatorname{sis}^{5}$.

The microscopic method of tuberculosis detection started with its invention. Although sputum smear microscopy remains the most relied technique for detection of TB for a long stretch, but its several limitations restrict its use as an efficient tool ${ }^{6}$. New microscopic techniques such Fluorescent microscopy, Front-loaded Microscopy, Sodium hydrochlorite microscopy are introduced and endorsed by WHO in past few years, with an expectation of more sensitive and specific detection of TB(Table 1).

Culture techniques have always been the gold standard in the diagnosis of extra-pulmonary, Multi drug-resistant (MDR) TB. This technique offers an advantage of best results in TB detection even in a low level of Mycobacterium tuberculosis. Plentiful Culture techniques are utilized in the sensitive detection of MTB, exclusively for the first line and secondline anti-tuberculosis drug-resistant cases (Table 2). Further, the molecular methods of TB detection are also utilized for MDR cases (Table 3). These techniques have improved turnaround time and are more sensitive in the early diagnosis of TB. Also techniques such as the Tuberculin skin test and interferon-gamma based assay are used for indirect detection of tuberculosis, however low sensitivity and specificity towards the result restrict their utility as efficient tools for detection of TB (Table 4).

\section{DISCUSSION}

Apart from these detection techniques, the focus of research is now shifting to advanced concept i.e., Tuberculosis Biosensors. As most of the cases of TB are recognized in developing countries, there is a strong need for a diagnostic tool that is quick, simple, and cost-effective.

Biosensors are the devices that convert the biochemical response from the reaction between enzymes, cell, organelles, antibodies, nucleic acid, and chemical compound into optical, thermal, and electrical signals. These are the analytical devices comprising sensor, signal processor, and storage device. Sensors act as an interface between the biological systems and instrument ${ }^{19-20}$.

Biosensors offer a number of advantages over the traditional techniques such as high specificity, rapid response, and provide better results with minimal quantity of sample. On the basis of the transducer principle, these are classified as Electrochemical, optical, mechanical, and magnetic biosensors which are further classified on the basis of their application as TB sensors including nanowires, electronic nose, breathalyser, etc. ${ }^{20-22}$.

\section{CONCLUSION}

By analyzing the current statistics provided by WHO, the impact of TB can be easily concluded. Tb remains a major health concern over the years. Despite using several medicaments and diagnostic techniques its control is still challenging in developing countries due to lack of awareness and fall in appropriate implementation of $\mathrm{Tb}$ prevention and control program $^{22}$. In developing countries where the cost of treatment is a major concern, traditional diagnostic techniques are still in use. Thus, leading to an increased percentage of false reports and delayed diagnosis. Newer microscopic and molecular techniques are however introduced with reduced turnaround time but these techniques require skilled personal due to complex procedures and are costly. Culture techniques are unparalleled in sensitivity but are quite timeconsuming. Both traditional and newer techniques have their advantages and disadvantages and thus cannot be replaced by each other ${ }^{23}$. However, for a better and safe world future research should continue to develop new techniques, which are simple, cheap, and effective in controlling the spread of TB worldwide. Biosensors for $\mathrm{Tb}$ diagnosis are the latest technology endeavor which in the future may prove to be highly beneficial and effective due to their precise detection, simple use, and low cost.

\section{ACKNOWLEDGEMENT}

Authors acknowledge the immense help received from the scholars whose articles are cited and included in references of this manuscript.

\section{Funding: N/A.}

Conflict of Interest: The authors declare no conflicts of interest. 


\section{REFERENCES}

1. Lixia Z, Xiaoxiao H, Dinggeng H, Kemin W, Dilan Q. Biosensing Technologies for Mycobacterium tuberculosis Detection: Status and New Developments. Clinical and Developmental Immunology2011; $1-8$.

2. Fogel N. Tuberculosis: A disease without boundaries. Tuberculosis 2015; 95(5):527-531.

3. Sandhu KG. Tuberculosis: Current situation, challenges and overview of its control programs in India. Journal of global infectious diseases. 2011; 2(3): 143-150.

4. Bansal R, Sharma D, Singh R. Tuberculosis and its treatment: An overview. Mini-Reviews in Medicinal Chemistry 2018; 18: 58-71.

5. World Health Organisation; Global Tuberculosis report; Executive summary 2019. Accessed on $20^{\text {th }}$ March 2020. https://www. who.int/tb/publications/global_report/en/

6. Oommen S, Banaji N. Laboratory diagnosis of tuberculosis: Advances in technology and drug susceptibility testing. Indian journal of medical microbiology2017; 35(3): 323-331.

7. Nyendak RM, Lewinsohn AD, Lewinsohn MD. New diagnostic methods for tuberculosis. Curr Opin Infect Dis 2009; 22(2): 174-182.

8. World Health Organisation.Fluorescent light-emitting diode (LED) microscopy for diagnosis of tuberculosis. 2011; 1-11. Accessed on $18^{\text {th }}$ March 2020 https://www.who.int/tb/publications/2011/led_microscopy_diagnosis_9789241501613/en/

9. Gammo M, Lamaric W, Ābuazza A, Askar NA, Yassin MA, Cueevas LE. Front loaded smear microscopy for the diagnosis of pulmonary TB in Tripoli, Libya 2013; 107(2): 137-9.

10. Bonnet M, Ramsay A, Githui W, Varaine F, Gureine JP. Bleach Sedimentation: An Opportunity to Optimize Smear Microscopy for Tuberculosis Diagnosis in Settings of High Prevalence of HIV. Clinical Infectious Diseases 2008; 46:1710-6.

11. Heifets L, Linder T, Sanchez T, Spencer D, Brennan J. Two Liquid Medium Systems, Mycobacteria Growth Indicator Tube and MB Redox Tube, for Mycobacterium tuberculosis Isolation from Sputum Specimens. Journal of Clinical Microbiology 2000; 38(3):1227-30.

12. Infantes MSD, Serrano RJM, Sanchez LM, Ortega Arturo, Bouza Emilio. Evaluation of the MB/BacT Mycobacterium Detec- tion System for Susceptibility Testing of Mycobacterium tuberculosis. J Clin Microbiol 2000; 38(5): 1988-89.

13. Thermo Fisher Scientific. VersaTREK TM Myco Bottles 2014; 7111-42. Accessed on $20^{\text {th }}$ March 2020. https://www.thermofisher.com/order/catalog/product/7111-42\#/7111-42

14. Shibabaw A. Accuracy of the color plate microscopy detection for the diagnosis of Mycobacterium tuberculosis complex in northwest Ethiopia. American Journal of Clinical Pathology 2018; s125-6.

15. Martin A, Portaels F, Groll V A. Thin- layer agar for detection of resistance of rifampicin, ofloxacin and kanyamacin in mycobacterium tuberculosis isolates. The International Journal of Tuberculosis and Lung Disease2009; 13(10): 1301-04.

16. Dihadenys L, Ernesto M, Miguel E, Anandi M, Franc, Oise P, Juan C P. Nitrate reductase assay for detection of drug resistance in Mycobacterium tuberculosis: simple and inexpensive method for low-resource laboratories. Journal of Medical Microbiology 2006; 55: 861-3.

17. Dewan R, Anuradha S, Khanna A, Garg S, Singla S, Ish P, et.al. Role of cartridge-based nucleic acid amplification test (CBNAAT) for early diagnosis of pulmonary tuberculosis in HIV. Journal, Indian Academy of Clinical Medicine 2015; 16(2): 1147.

18. Ruvandhi RN, Cudahy P, Schumacher SG, Steingart KR, Pai M, Claudia MD. Accuracy of line probe assays for the diagnosis of pulmonary and multidrug resistant tuberculosis: a systematic review and meta-analysis. Eur Respir J2017; 49: 1-23.

19. Regatieri A, Abdel Wahed Y, Perez MT, Bush LM. Testing for Tuberculosis: The Roles of Tuberculin Skin Tests and Interferon Gamma Release Assays. Lab medicine 2011; 42(1): 12-16.

20. Srivastava KS, Rijan JMC, Jongsma MA. Biosensor-based detection of tuberculosis. Royal Society of Chemistry 2016; 6: 17759-17771.

21. Srivastava KS, Biosensor based detection of tuberculosis biomarkers. Ph.D thesis. Wegeningen University, Wegeningen 2014. Accessed on $24^{\text {th }}$ March 2020.https://edepot.wur.nl/324299.

22. Kaur N, Bhatia SS. Tuberculosis diagnosis and treatment: Negotiating the solution and implementations. International Journal of current research and review 2013; 5(6):69-75.

23. Eddabra R, Benhassou HA. Rapid molecular assays for detection of tuberculosis. Pneumonia 2018; 10 (4): 2-12.

\section{Table 1: Microscopic techniques for the direct detection of Mycobacterium tuberculosis}

\begin{tabular}{|c|c|c|c|c|}
\hline \multicolumn{5}{|c|}{ Direct detection of actively growing bacilli (Microscopic technique) } \\
\hline S. No. & Technique & Principle & Advantages & limitations \\
\hline 1. & $\begin{array}{l}\text { Sputum Smear micros- } \\
\text { copy }^{7}\end{array}$ & $\begin{array}{l}\text { Acid-fast staining using carbol } \\
\text { fuschin and fluorochrome dye- } \\
\text { auramine/rhodamine. }\end{array}$ & $\begin{array}{l}\text { Fast technique, } \\
\text { Expensive }\end{array}$ & $\begin{array}{l}\text { Low sensitivity (detect less than } \\
50 \% \text { active cases). } \\
\text { Cannot detect multidrug resistant } \\
\text { cases or non-tuberculous myco- } \\
\text { bacteria. }\end{array}$ \\
\hline 2. & $\begin{array}{l}\text { Fluorescent micros- } \\
\text { copy with light emitting } \\
\text { diode. }\end{array}$ & $\begin{array}{l}\text { Use of royal blue colour LED } \\
\text { lamps. }\end{array}$ & $\begin{array}{l}\text { Economical, } \\
\text { Better sensitivity, } \\
\text { Rapid detection (four } \\
\text { times faster than con- } \\
\text { ventional FM). }\end{array}$ & $\begin{array}{l}\text { Instability of fluorescent stains } \\
\text { under fluid conditions. }\end{array}$ \\
\hline 3. & $\begin{array}{l}\text { Front loaded Micros- } \\
\text { copy }^{9}\end{array}$ & $\begin{array}{l}\text { Collection of two specimens at } \\
\text { a time interval of } 1 \mathrm{hr} \text {. }\end{array}$ & Fast diagnosis. & - \\
\hline 4 & $\begin{array}{l}\text { Sodium hydrochlorite } \\
\text { (Bleach) microscopy }{ }^{10}\end{array}$ & $\begin{array}{l}\text { Digestion of sputum with So- } \\
\text { dium hydrochlorite, before the } \\
\text { sputum smear preparation and } \\
\text { microscopy. }\end{array}$ & $\begin{array}{l}\text { Improved sensitivity } \\
\text { and specificity. }\end{array}$ & $\begin{array}{l}\text { Due to lack of standardization in } \\
\text { results, problem in method devel- } \\
\text { opment phase. }\end{array}$ \\
\hline
\end{tabular}


Table 1: (Continued)

\begin{tabular}{|c|c|c|c|c|}
\hline \multicolumn{5}{|c|}{ Direct detection of actively growing bacilli (Microscopic technique) } \\
\hline S. No. & Technique & Principle & Advantages & limitations \\
\hline 5 & $\begin{array}{l}\text { Vital Fluorescent stain- } \\
\text { ing }^{6}\end{array}$ & $\begin{array}{l}\text { Based on fluorescent viability } \\
\text { markers, fluoresin diacetate } \\
\text { (FDA) }\end{array}$ & $\begin{array}{l}\text { Useful for diagnosis of } \\
\text { rifampicin-resistant } \\
\text { tuberculosis. }\end{array}$ & - \\
\hline 6. & Urine based assays $^{6}$ & $\begin{array}{l}\text { Lipoararabinomannan antigen } \\
\text { present on cell wall of MTB. }\end{array}$ & & $\begin{array}{l}\text { Low accuracy }(28.3 \%) \text { and fails to } \\
\text { differentiate between active and } \\
\text { latent cases. }\end{array}$ \\
\hline
\end{tabular}

Table 2: Culture techniques for direct detection of actively growing bacilli.

\begin{tabular}{|c|c|c|c|c|}
\hline \multicolumn{5}{|c|}{ Direct detection of actively growing bacilli (Culture technique) } \\
\hline S. No. & Technique & Principle & $\begin{array}{l}\text { Turnaround time } \\
\text { (TAT) }\end{array}$ & Utility \\
\hline 1. & $\begin{array}{l}\text { Mycobacterial growth } \\
\text { indicator tube (MGIT) }{ }^{11}\end{array}$ & $\begin{array}{l}\text { Detect the consumption of oxygen by } \\
\text { fluorescence. }\end{array}$ & 9-16 days & $\begin{array}{l}\text { Used for extra pulmonary } \\
\text { Tuberculosis cases. }\end{array}$ \\
\hline 2. & $\mathrm{MB} / \mathrm{BacT}^{12}$ & $\begin{array}{l}\text { Measure Carbon dioxide produced by } \\
\text { microbial growth. }\end{array}$ & 11.8 days. & $\begin{array}{l}\text { Detect the isoniazid, } \\
\text { rifampicin, streptomycin- } \\
\text { susceptible and isoniazid- re- } \\
\text { sistant cases. }\end{array}$ \\
\hline 3. & Versa TREK/ESP³ & $\begin{array}{l}\text { Measurement on the basis of oxygen } \\
\text { consumption. }\end{array}$ & 19.1 days & $\begin{array}{l}\text { Work as an Automated } \\
\text { Microbial Detection System } \\
\text { (VTI) for the recovery of } \\
\text { mycobacteria. }\end{array}$ \\
\hline $4 \cdot$ & $\begin{array}{l}\text { Micro-colony detec- } \\
\text { tion }^{14}\end{array}$ & $\begin{array}{l}\text { Solid and Liquid cultures in micro- } \\
\text { plates. }\end{array}$ & 9-12 days for culture & $\begin{array}{l}\text { Detect pulmonary tubercu- } \\
\text { losis }\end{array}$ \\
\hline 5. & Thin layer agar ${ }^{15}$ & Use TLA quadrant plate & 10 days & $\begin{array}{l}\text { Rapid detection of MTB } \\
\text { bacterial strains resistant to } \\
\text { rifampicin, ofloxacin and } \\
\text { kanamycin. }\end{array}$ \\
\hline 6. & Nitrate reduction assay ${ }^{16}$ & Colorimetric detection of nitrite & 10-15 days & $\begin{array}{l}\text { Accurate detection of First - } \\
\text { line Antituberculous drugs } \\
\text { resistant strains of bacteria. }\end{array}$ \\
\hline
\end{tabular}

Table 3: Molecular methods for the direct detection of Mycobacterium tuberculosis.

\begin{tabular}{|c|c|c|c|c|c|c|}
\hline \multirow[b]{2}{*}{ S. No. } & \multicolumn{6}{|c|}{$\begin{array}{l}\text { Direct detection of MTB by Molecular method } \\
\text { Nucleic acid amplification test (NAAT) }\end{array}$} \\
\hline & Technique & Utility & $\begin{array}{l}\text { Analytical } \\
\text { limit }\end{array}$ & $\begin{array}{l}\text { Turnaround } \\
\text { time (TAT) }\end{array}$ & Sensitivity & Limitations \\
\hline $1 a$. & $\begin{array}{l}\text { Cartridge based } \\
\text { NAAT (CB- } \\
\text { NAAT })^{17}\end{array}$ & $\begin{array}{l}\text { Diagnose both } \\
\text { pulmonary and } \\
\text { extrapulmonary } \\
\text { Tuberculosis. }\end{array}$ & $131 \mathrm{CFU} / \mathrm{ml}$ & $2 \mathrm{hr}$ & $\begin{array}{l}99.8 \% \text { sensitivity for smear } \\
\text { positive and culture positive } \\
\text { cases } \\
90.2 \% \text { sensitivity for smear } \\
\text { negative, culture positive } \\
\text { cases. }\end{array}$ & $\begin{array}{l}\text { Mono-resistant } \\
\text { cases of isoniazid } \\
\text { (INH) cannot be } \\
\text { detected. }\end{array}$ \\
\hline $\mathrm{lb}$ & $\begin{array}{l}\text { Line Probe assay } \\
(\text { LPA })^{18}\end{array}$ & $\begin{array}{l}\text { Detect Isoniazid } \\
\text { and rifampicin } \\
\text { resistant cases. }\end{array}$ & - & - & $\begin{array}{l}98.9 \% \text { sensitivity for the de- } \\
\text { tection of rifampicin (RIF) } \\
\text { resistant cases. } \\
94.2 \% \text { sensitivity for } \\
\text { isoniazid (INH) resistant } \\
\text { cases. }\end{array}$ & $\begin{array}{l}\text { Complex procedure. } \\
\text { Require skilled } \\
\text { personals. }\end{array}$ \\
\hline
\end{tabular}


Table 4: Techniques for indirect detection of Mycobacterium tuberculosis

\begin{tabular}{|c|c|c|c|}
\hline \multicolumn{4}{|c|}{ Indirect detection of immune response against the bacilli ${ }^{19}$} \\
\hline S. No. & Technique & Principle & Limitations \\
\hline 1. & Tuberculin skin test & $\begin{array}{l}\text { Sub-cutaneous injection of protein } \\
\text { purified derivative from sub culture of } \\
\text { MTB bacteria. }\end{array}$ & $\begin{array}{l}\text { Immuno-deficient subject failed to generate } \\
\text { sufficient response. }\end{array}$ \\
\hline 2. & $\begin{array}{l}\text { Interferon gamma based } \\
\text { assay }\end{array}$ & $\begin{array}{l}\text { Detect the specific T-cell response to } \\
\text { Mycobacterium tuberculosis antigens }\end{array}$ & $\begin{array}{l}\text { Expensive. } \\
\text { Low specificity and sensitivity. }\end{array}$ \\
\hline
\end{tabular}

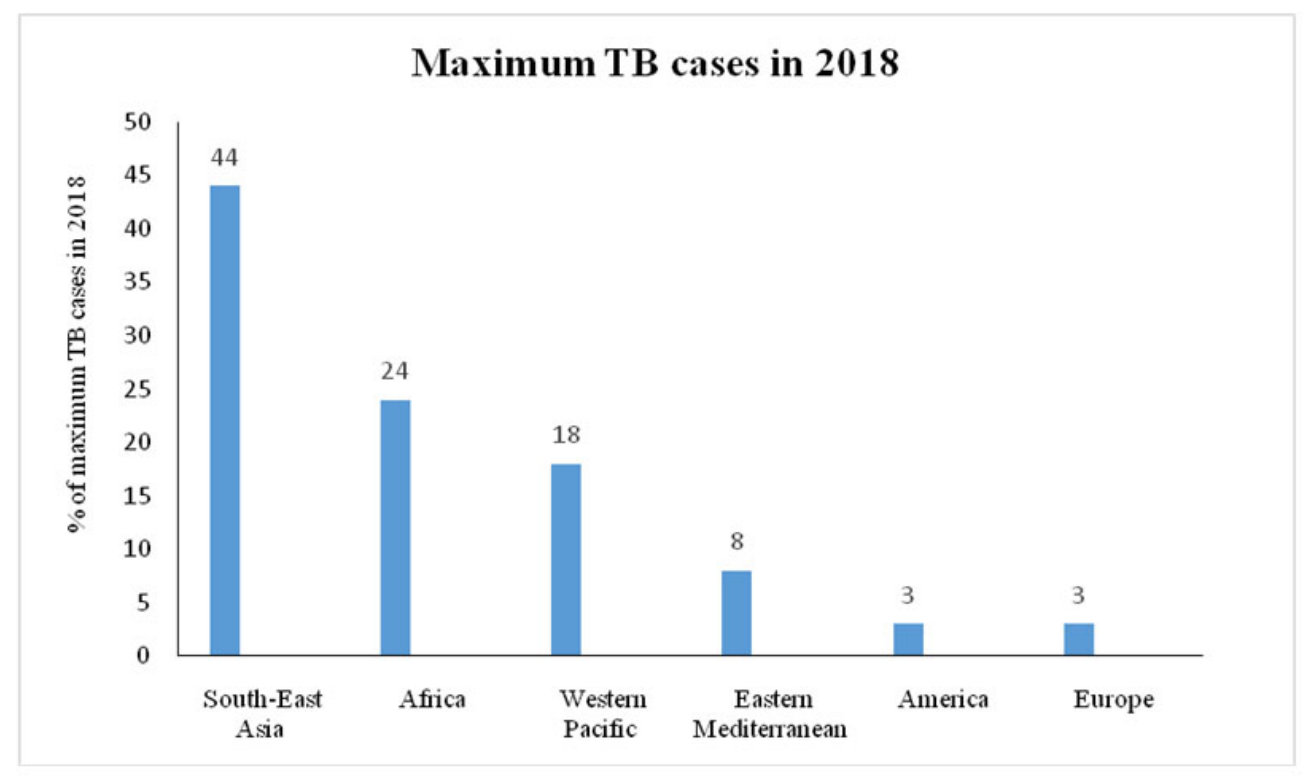

Figure 1: Percentage of tuberculosis cases worldwide in 2018 (WHO report 2019. 